\title{
POLA PENGGUNAAN OBAT PADA PASIEN STROKE HEMORAGIK DI RSUP PROF. DR. R.D. KANDOU MANADO PERIODE JANUARI- DESEMBER 2018
}

\author{
Nony L. Poana ${ }^{1)}$, Weny I. Wiyono ${ }^{1)}$, Deby A. Mpila ${ }^{1)}$ \\ ${ }^{1)}$ Program Studi Farmasi FMIPA UNSRAT Manado, 95115
}

\begin{abstract}
ABSTRACK
Hemorrhagic stroke is a stroke caused by intracerebral hemorrhage or subarachniod hemorrhage due to rupture of cerebral blood vessels in certain areas, so that blood fills the brain tissue. The selection and use of drugs must be rational, so that treatment can achieve maximum therapy with minimal side effects. The purpose of this study was to determine the characteristics and patterns of drug use in hemorrhagic stroke patients at Prof. RSUP Dr. R.D. Kandou Manado. This study uses a descriptive method with a retrospective research design. The sample of this study were 83 patients, including 70 intracerebral hemorrhagic stroke patients and 13 subarachnoid hemorrhagic stroke patients. Patient characteristics were mostly male as many as 46 patients (55.42\%) and female as many as 37 patients (44.58\%). The largest age range of hemorrhagic stroke patients at the age of 5564 years was 27 patients (32.52\%). The duration of treatment with the highest prevalence was 1-5 days in 37 patients (44.57\%). Hypertension is the most common comorbid disease of 60 patients (40.27\%), and cholesterol of 15 patients (10.06). The pattern of drug use based on the evaluation of the right indication as many as 83 patients (100\%), the right patients as many as 83 patients (100\%), the right drugs as many as 82 patients (98.8\%), and the right dosage of 73 patients (87.95\%).
\end{abstract}

Keywords: Hemorrhagic stroke, drug use

\begin{abstract}
ABSTRAK
Stroke hemoragik adalah stroke yang disebabkan oleh perdarahan intraserebral atau perdarahan subarakhniod karena pecahnya pembuluh darah otak pada area tertentu, sehingga darah memenuhi jaringan otak. Pemilihan dan penggunaan obat harus secara rasional, sehingga pengobatan dapat mencapai terapi yang maksimal dengan efek samping minimal. Tujuan dari penelitian ini untuk mengetahui karakteristik dan pola penggunaan obat pada pasien stroke hemoragik di RSUP Prof. Dr. R.D. Kandou Manado. Penelitian ini menggunakan metode deskriptif dengan desain penelitian retrospektif. Sampel penelitian ini sebanyak 83 pasien, diantaranya terdapat 70 pasien stroke hemoragik intraserebral dan 13 pasien stroke hemoragik subarakhnoid. Karakteristik pasien sebagian besar adalah laki-laki sebanyak 46 pasien $(55,42 \%)$ dan perempuan sebanyak 37 pasien $(44,58 \%)$. Rentang usia pasien stroke hemoragik terbesar pada usia 55-64 tahun sebanyak 27 pasien $(32,52 \%)$. Lama perawatan dengan prevalensi paling banyak, yaitu $1-5$ hari pada 37 pasien $(44,57 \%)$. Hipertensi merupakan penyakit penyerta yang paling banyak diderita sebesar 60 pasien (40,27\%), dan kolestrol sebanyak 15 pasien $(10,06)$. Pola penggunaan obat berdasarkan evaluasi tepat indikasi sebanyak 83 pasien $(100 \%)$, tepat pasien sebanyak 83 pasien (100\%), tepat obat sebanyak 82 pasien $(98,8 \%)$, dan tepat dosis sebanyak 73 pasien $(87,95 \%)$.
\end{abstract}

Kata kunci : stroke hemoragik, pola penggunaan obat 


\section{PENDAHULUAN}

Secara global, hampir $80 \%$ kejadian stroke banyak dijumpai di Negara miskin dan berkembang, yang mengancam kehidupan, kesehatan dan kualitas hidup. Stroke sebagai masalah utama bagi kesehatan masyarakat karena menjadi penyebab dari banyak penyakit, kecacatan dan kematian (WHO, 2016). Di Indonesia, diperkirakan setiap tahun terdapat 500.000 penduduk terkena serangan stroke, sekitar 2,5\% atau 125.000 orang meninggal, dan sisanya cacat ringat maupun berat. Provinsi Sulawesi Utara menempati urutan teratas dalam hal prevalensi stroke yang terdiagnosis oleh tenaga kesehatan yakni sebesar 10,8 kasus per mil. Prevalensi tertinggi kedua dari Yogyakarta (10,3 per mil), diikuti Bangka Belitung (9,7 per mil), DKI Jakarta (9,7 per mil) dan Kalimantan Selatan (9,2 per mil) (Pokdi Stroke, 2011; Depkes, 2013). Dalam data statistik pasien tahun 2012, dari 10 penyakit terbanyak di Instalasi Rehabilitas Medik RSUP Prof. Dr. R. D. Kandou Manado, stroke menempati posisi kedua dengan persentase 24\% (Andrew dkk, 2016).

Secara umum, tujuan terapi farmakologis pada pasien stroke adalah untuk mengurangi cedera neuologis dan penurunan angka kematian, serta kecacatan jangka panjang (Perdossi, 2011). Manajemen stroke hemoragik dapat dilihat dari penyebab perdarahan yang terjadi, seperti hipertensi, penggunaan obat-obat antikoagulan, trauma kepala, serta malformasi pembuluh darah (Louis R.C dkk, 2015). Perawatan medis yang dapat dilakukan secara farmakologis pada pasien stroke hemoragik adalah dengan terapi neuroprotektan, diuretik osmotik, antikoagulan,antifibrinolitik, antihipertensi dan antidisiplidemia (Jagtap P.N, 2013).

Pemilihan dan penggunaan obat harus secara rasional, sehingga pengobatan dapat mencapai terapi yang maksimal dengan efek samping minimal. Penggunaan obat yang tidak rasional akan memberikan dampak yang merugikan bagi instansi pelayanan kesehatan, pasien dan masyarakat (Munaf, 2004). Berdasarkan uraian tersebut, maka peneliti menganggap bahwa penelitian tentang "Pola Penggunaan Obat Pada Pasien Stroke Hemoragik di RSUP Prof.Dr.R.D.Kandou Periode Januari Desember 2018" perlu dilakukan.

\section{METODOLOGI PENELITIAN Tempat dan Waktu Penelitian}

Penelitian ini akan dilakukan di bagian Instalasi Rekam Medik RSUP Prof. Dr. R. D. Kandou Manado pada bulan Juni - Agustus 2019.

\section{Jenis Penelitian}

Penelitian ini menggunakan metode deskriptif dengan desain penelitian retrospektif di RSUP. Prof. Dr. R.D. Kandou manado, dimana data penelitian menggunakan data sekunder yaitu dengan melihat hasil rekam medis pasien berupa data karakteristik pasien, obat-obatan yang digunakan, pemeriksaan fisik dan hasil laboratorium.

\section{Subyek Penelitian}

Subyek dalam penelitian ini adalah semua pasien rawat inap dengan diagnosa stroke hemoragik di RSUP. Prof. Dr. R.D. Kandou Manado pada periode bulan Januari 2018 - Desember 2018 yang memenuhi kriteria inklusi dan eksklusi sebagai berikut : 
a. Kriteria inklusi :

2. Pasien dengan diagnosa stroke hemoragik yang tertera dalam rekam medik yang mendapatkan terapi obat.

3. Pasien stroke hemoragik dengan atau tanpa penyakit penyerta.

b. Kriteria eksklusi :

1. Data rekam medis tidak lengkap, misalnya tidak tercatat nama, jenis kelamin, usia, diagnosa.

HASIL

Dari hasil penelitian, didapatkan data karakteristik pasien, gambaran penggunaan obat dan kriteria ketepatan penggunaan obat pada pasien stroke hemoragik di instalasi rawat inap RSUP Prof. Dr. R. D. Kandou Manado dapat dilihat pada tabel dibawah ini.

\begin{tabular}{|c|c|c|c|c|}
\hline No & Variahel & Kategori & $\begin{array}{l}\text { Jumlah } \\
\text { Pasien } \\
(\mathrm{n}-83)\end{array}$ & $\begin{array}{c}\text { Persentase } \\
\text { (\%) }\end{array}$ \\
\hline \multirow[t]{2}{*}{$\mathrm{t}}$. & Jenis kelamin & Laki-laki & 46 & 35,42 \\
\hline & & Perempuas & 37 & 44,58 \\
\hline \multirow[t]{7}{*}{2.} & Usia* & <15-24 tabum & 0 & 0 \\
\hline & & 25-36 tilho & 0 & 0 \\
\hline & & 35-44 tathm & 9 & 10,84 \\
\hline & & 45-54 tahm & 39 & 22,9 \\
\hline & & 55-64 then & 27 & 32,52 \\
\hline & & $65-74$ talton & 19 & 229 \\
\hline & & $>75$ thun & 9 & 10,84 \\
\hline \multirow[t]{2}{*}{3.} & Jeris stroke & Intrasetebral & 20 & 84,34 \\
\hline & bemoragik & Subaralknoid & 13 & 15,66 \\
\hline & Lama ratat insp"* & 1-5 bai & 37 & 44,57 \\
\hline & & $6-10$ han & 24 & 28,91 \\
\hline & & $11-15$ bari & 15 & 18,07 \\
\hline
\end{tabular}

1. Pasien dengan usia $\geq 15$ tahun (Kemenkes RI, 2013)

\section{Analisis Data}

Data yang telah dikumpulkan di Lembar Pengumpulan Data (LPD) dilakukan analisis deskriptif, dengan mengidentifikasi karateristik pasien, serta menggambarkan ketepatan penggunaan obat pada pasien stroke hemoragik di instalasi rawat inap RSUP. Prof. Dr. R.D. Kandou Manado yang terdiri dari tepat indikasi, tepat obat,tepat dosis dan tepat pasien.

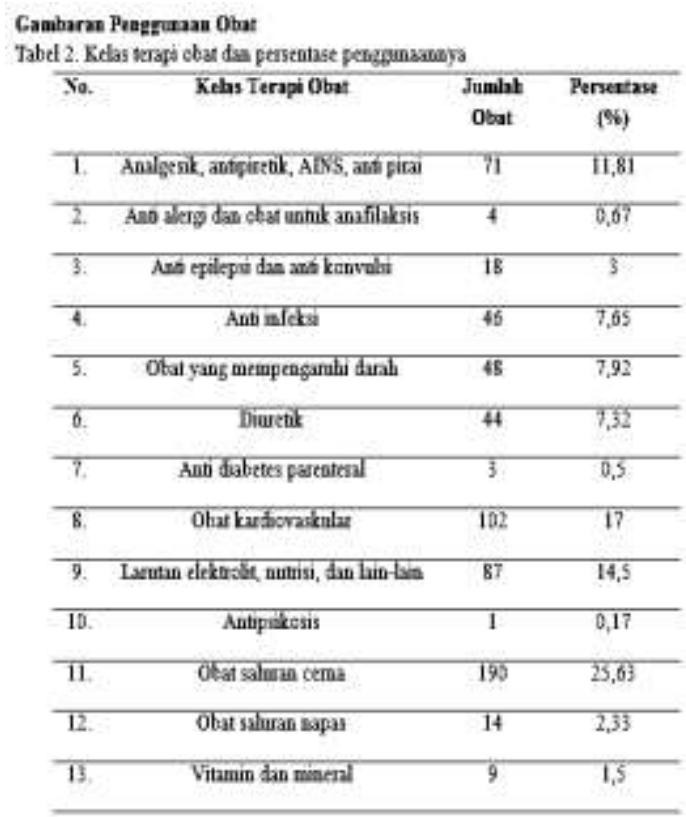

\begin{tabular}{|c|c|c|c|c|}
\hline \multirow{3}{*}{$\begin{array}{c}\text { Kriteria } \\
\text { Keteprtan }\end{array}$} & \multicolumn{4}{|c|}{ Fralued Pengyuman Ohat } \\
\hline & \multicolumn{2}{|c|}{ Tepat } & \multicolumn{2}{|c|}{ Tidak Tepat } \\
\hline & $\mathrm{N}$ & 36 & $\mathrm{~N}$ & 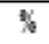 \\
\hline Indilkai & 83 & $\lfloor\hat{p}$ & 0 & 0 \\
\hline Prisian & 83 & (î) & 0 & 0 \\
\hline Ohat & 82 & 38,8 & 1 & 12 \\
\hline Dxis & 73 & 87,95 & 10 & 12,05 \\
\hline
\end{tabular}




\section{PEMBAHASAN}

\section{Karakteristik Pasien Berdasarkan Jenis Kelamin}

Berdasarkan tabel 1, dapat dilihat bahwa pasien dengan diagnosis stroke hemoragik lebih banyak terjadi pasien berjenis kelamin laki-laki sebanyak 46 pasien $(55,43 \%)$ dibandingkan dengan perempuan sebanyak 37 pasien $(44,57 \%)$. Jumlah pasien perempuan yang menderita stroke hemoragik ini lebih sedikit dibandingkan laki-laki dikarenakan adanya pengaruh hormon estrogen yang berperan dalam meningkatkan High Density Lipoprotein (HDL). Kolestrol HDL dalam kadar yang tinggi dapat menjadi faktor pelindung dalam mencegah terjadinya proses aterosklerosis. Terjadinya aterosklerosis dalam jangka waktu yang panjang akan menyebabkan penebalan serta pengerasan arteri. Sumbaran pada pembuluh darah ini dapat pecah secara mendadak sehingga menyebabkan darah membeku di daerah sekitar pembuluh darah arteri yang pecah. Apabila hal ini terjadi di otak, maka dapat menyebabkan stroke. Efek perlindungan estrogen ini dianggap sebagai penjelasan mengenai adanya imunitas perempuan pada rentang usia premenopause (Kumar dkk, 2005). Lebih tingginya risiko terkena stroke pada lakilaki sebagian besar dipengaruhi oleh gaya hidup laki-laki seperti merokok, kurang aktivitas fisik, dan minuman alkohol (Ghani, 2016).

\section{Karakteristik Pasien Berdasarkan Usia}

Berdasarkan data yang diperoleh pada penelitian ini yang tertera pada tabel 1, pasien berumur 45-64 tahun memiliki persentase paling tinggi $(63,85 \%)$ kemudian diikuti oleh pasien yang berusia $>65$ tahun $(26,51 \%)$ dan persentase paling rendah yaitu pada usia $<45$ tahun $(9,64 \%)$. Hasil ini mendekati dengan hasil penelitian profil stroke di Indonesia yang dilakukan oleh survey ASNA (Asean Neurologic Association) di 28 rumah sakit diseluruh Indonesia pada penderita stroke akut yang dirawat di rumah sakit, hasil penelitian menunjukkan bahwa penderita laki-laki lebih banyak dari perempuan dan profil usia dibawah 45 tahun cukup banyak yaitu 11,8\%, usia 45-64 tahun berjumlah 54,7\% dan diatas usia 65 tahun sebanyak 33,5\% (Misbach, 2001).

\section{Karakteristik Pasien Berdasarkan Jenis Stroke Hemoragik}

Berdasarkan hasil penelitian yang tertera pada tabel 1, prevalensi stroke hemoragik intraserebral sebanyak 70 pasien $(84,34 \%)$, Sedangkan, prevalensi stroke hemoragik subarakhnoid sebanyak 13 pasien $(15,66 \%)$. Hal ini disebabkan karena banyaknya jumlah pasien stroke dengan penyakit penyerta tekanan darah tinggi (hipertensi) yang menyebabkan tingginya tekanan di dinding arteri sehingga bisa menyebabkan bocornya arteri otak, bahkan ruptur pada arteri otak yang akan mengakibatkan terjadinya stroke hemoragik (Silva dkk, 2014).

\section{Karakteristik pasien Berdasarkan Penyakit Penyerta}

Berdasarkan Tabel 1, didapatkan bahwa mayoritas responden mempunyai penyakit penyerta hipertensi. Hal ini disebabkan karena, stroke merupakan penyakit yang berhubungan dengan sirkulasi darah, khususnya sirkulasi darah 
di otak. Dalam patofisiologi stroke adanya embolus, trombus, dan perdarahan merupakan faktor penyebab terjadinya stroke. Jika ketiga hal tersebut dapat diatasi, maka akan memberikan hasil terapi yang baik yang ditandai dengan tingginya angka kesembuhan pada pasien (Meita Krismayanti, 2007).

Berdasarkan penelitian dari Khan et al (2014), stroke dapat disebabkan oleh kolestrol yang merupakan jumlah lipid yang abnormal di dalam darah, seperti adanya peningkatan kadar kolestrol total, peningkatan trigliserida, ataupun penurunan kadar High Density Lipoprotein (HDL). Kadar kolestrol total yang rendah akan menyebabkan endotel serebrovaskuler menjadi rapuh, sehingga lebih rentan terhadap terjadinya mikroaneurisma yang merupakan temuan patologis utama pada perdarahan intraserebral (ICH) (Wang et al, 2013).

\section{Karakteristik Pasien Berdasarkan Lama Rawat Inap}

Lama perawatan pasien stroke dalam penelitian ini dihitung dalam jumlah hari, berdasarkan saat pasien mulai terdaftar sebagai pasien rawat inap. Berdasarkan hasil penelitian pada tabel 1, diperoleh hasil lama rawat inap $<5$ hari sebanyak 44,58\% (37 pasien), 6-10 hari sebanyak $28,91 \%$ (24 pasien ), 11-15 hari sebanyak $18,08 \%$ (15 pasien) dan $>15$ hari sebanyak $8,43 \%$ (7 pasien ). Lama rawat inap berhubungan juga dengan adanya komplikasi medis pada pasien stroke selama masa perawatan yang akan mempengaruhi kecepatan perbaikan kondisi klinis pasien dan berdampak pada lama rawat inap pasien (Johnsen dkk, 2012).

\section{Gambaran Penggunaan Obat}

\section{Obat analgesik, antipiretik, AINS, anti pirai}

Berdasarkan Tabel 2, pasien stroke hemoragik yang dirawat inap di RSUP Prof. Dr. R. D. Kandou Manado yang menerima terapi obat analgesik non narkotik sebanyak 71 obat $(11,81 \%)$. Dengan pilihan obat paracetamol yang paling banyak digunakan. Penggunaan paracetamol ini disebabkan karena pasien stroke juga disertai demam (hipertemi) yang ditandai dengan peningkatan suhu tubuh mencapai $37,5^{\circ} \mathrm{C}$ setelah 48 jam onset stroke. Hipertemi diatasi dengan pemberian antipiretik, dosis yang diberikan adalah $500 \mathrm{mg}$ hingga 4 kali sehari bila perlu. Penggunaan bila perlu dimaksudkan hanya pada saat suhu tubuh naik, jika suhu tubuh pasien kembali normal penggunaan antipiretik dihentikan. Penggunaan paracetamol yang melebihi dosis yang dianjurkan dalam jangka waktu lam dapat menyebabkan kerusakan hati sehingga penggunaannya perlu dikontrol ( Adams dkk, 2003).

\section{Anti alergi dan obat untuk anafilaksis}

Berdasarkan Tabel 2, pasien yang menerima terapi obat anti alergi dan obat untuk anafilaksis sebanyak 4 pasien $(0,67 \%)$, dengan pilihan obat dexamethasone yang digunakan untuk menghambat pembentukan edema akibat cedera kepala pada perdarahan serebral yang diantaranya subdural, epidural, intraserebral, dan batang otak (Doenges, 2000).

\section{Antiepilepsi dan antikonvulsi}

Berdasarkan Tabel 2, pasien yang menerima terapi obat antiepilepsi dan antikonvulsi sebanyak 18 pasien (3\%), 
dengan pilihan obat fenitoin yang paling banyak digunakan untuk hampir semua jenis epilepsi atau kejang, kecuali bangkitan lena. Kejang merupakan gejala neurologis paling umum terjadi pada penderita stroke usia lanjut. Hal ini sering terjadi pada pasien dengan malformasi arteriovenosa, stroke batang otak, perdarahan subarakhnoid atau riwayat kejang atau epilepsi (Bladin CF, Alexandrov AV, et al, 2000).

\section{Anti infeksi}

Berdasarkan Tabel 2, pasien yang menerima terapi obat antibakteri sebanyak 46 pasien $(7,65 \%)$, dengan pilihan obat ceftriaxone yang paling banyak digunakan dibandingkan antibakteri lain. Obat ini sekarang merupakan pilihan utama untuk uretritis oleh gonokokus tanpa komplikasi (Gunawan, 2009). Antiinfeksi yang digunakan pada kasus penelitian ini umumnya diberikan untuk mencegah atau mengobati kejadian infeksi saluran kemih, pneumonia dan infeksi nosokomial dari pasien rawat inap, yang memiliki resiko sangat besar untuk terinfeksi.

\section{Obat yang mempengaruhi darah}

Berdasarkan Tabel 2, pasien yang menerima terapi obat yang mempengaruhi koagulasi sebanyak 48 pasien (7,92\%), dengan pilihan obat asam traneksamat yang digunakan untuk mencegah terjadinya perdarahan ulang pasca serangan stroke perdarahan. Perdarahan ulang ini berdampak buruk karena dapat mengakibatkan penurunan kesadaran bahkan kematian (Christianus, 2014).

\section{Diuretik}

Berdasakan Tabel 2, pasien yang menerima terapi obat diuretik sebanyak 44 pasien $(7,32 \%)$, dengan pilihan obat manitol yang paling banyak digunakan untuk menurunkan tekanan intrakranial pada otak. Manitol diperkirakan menurunkan TIK dengan cara mengurangi kadar air keseluruhan dan volume cairan serebrospinal serta dengan mengurangi volume darah melalui vasokonstriksi. Manitol juga dapat meningkatkan perfusi otak dengan mengurangi viskositas (Bereczki dkk, 2000).

\section{Antidiabetes parenteral}

Berdasarkan Tabel 2, pasien yang menerima terapi obat antidiabetes parenteral sebanyak 3 pasien $(0,5 \%)$. Novorapid merupakan insulin yang memiliki waktu kerja sangat cepat sekitar 3-5 jam yang digunakan untuk pasien stroke hemoragik dengan penyakit diabetes melitus tipe 2. Mempertahankan kondisi normoglikemia menjadi bagian yang penting dalam penatalaksanaan stroke. Kadar gula darah diusahakan secepat mungkin dikontrol dalam rentang 100-150 $\mathrm{mgl} / \mathrm{dL}$. Sedangkan untuk penderita diabetes melitus, disarankan target gula darah antara 100-200 mg/dL (Deibert \& Diringer, 1999).

\section{Obat kardiovaskular}

Berdasarkan Tabel 2, pasien yang menerima terapi obat kardiovaskular sebanyak 102 pasien (17\%), dengan pilihan obat amlodipin paling banyak digunakan untuk menurunkan tekanan darah pada pasien stroke hemoragik. Pemantauan tekanan darah pasien sangat diperlukan untuk membantu pengambilan keputusan bagi para klinis untuk memberikan terapi antihipertensi (Rincon \& Mayer, 2005). 


\section{Larutan elektrolit, nutrisi, dan lain- lain}

Berdasarkan Tabel 2, pasien yang menerima terapi larutan elektrolit, nutrisi, dan lain-lain sebanyak 87 pasien $(14,5 \%)$, dengan pilihan larutan elektrolit $\mathrm{NaCL}$ yang paling banyak digunakan sebagai penanganan pertama pada pasien stroke hemoragik untuk menghindari terjadinya dehidrasi yang akan meningkatkan viskositas darah.

\section{Antipsikosis}

Berdasarkan Tabel 2, pasien yang menerima terapi antipsikosis sebanyak 1 pasien $(0,17 \%)$, Dengan pilihan terapi obat risperidone yang digunakan untuk psikotik akut karena mempunyai efektivitas yang baik, efek samping minimal, dan relatif aman dapat ditoleransi dengan baik (Waney AT, 2005).

\section{Obat saluran cerna}

Berdasarkan Tabel 5, pasien yang menerima terapi obat saluran cerna sebanyak 190 pasien $(25,63 \%)$, dengan pilihan obat ranitidine yang paling banyak digunakan. Karena, pasien stroke hemoragik ada yang memiliki masalah pada lambung. Selain itu juga, untuk mencegah terjadinya stress ulcer, serta mengatasi obat-obat yang berefek samping pada lambung, akibat pemakaian antiplatelet dan obat non steroid (NSAID) (Abraham dkk, 2010).

\section{Obat saluran napas}

Berdasarkan Tabel 5, pasien yang menerima tepai obat saluran napas sebanyak 14 pasien (2,33\%). Dengan pilihan terapi combivent yang diberikan pada pasien yang memiliki keluhan sesak napas. Selain itu,adapun pasien yang menerima terapi ekspetoran sebanyak 9 pasien $(0,15 \%)$, dengan pilihan obat N.Asetil Sistein yang digunakan untuk mengurangi dahak yang menghalangi saluran pernapasan.

\section{Vitamin dan mineral}

Berdasarkan Tabel 5, pasien yang menerima terapi vitamin dan mineral sebanyak 9 pasien $(0,15 \%)$, dengan pilihan utama vitamin C. Karena penggunaan vitamin pada pasien stroke berhubungan dengan kadar homosistein dalam darah. Homosistein merupakan salah satu faktor risiko stroke yang apabila kadarnya didalam darah tinggi maka risiko stroke akan meningkat. Kadar homosistein yang tinggi akan bersifat aterogenik dan protrombus. Kadar homosistein dalam darah ditentukan oleh asam amino esensial metionin yang dihasilkan oleh faktor genetik, konsumsi vitamin dan asam folat. Dengan konsumsi vitamin dan asam folat tersebut akan mengurangi kadar homosistein dalam darah.

\subsubsection{Evaluasi Pola Penggunaan Obat}

Evaluasi pola penggunaan obat dilakukan terhadap 83 data rekam medik pasien stroke hemoragik rawat inap di RSUP Prof. Dr. R. D. Kandou Manado. Evaluasi pola penggunaan obat yang dilakukan meliputi beberapa kriteria yaitu, tepat indikasi, tepat pasien, tepat obat, dan tepat dosis, sebagai berikut.

\section{Tepat indikasi}

Menurut Kemenkes RI (2011), setiap obat memiliki spektrum terapi yang spesifik. Antibiotik, misalnya diindikasikan untuk infeksi bakteri. Dengan demikian, pemberian obat ini hanya dianjurkan untuk pasien yang memberi gejala adanya infeksi. 
Dari hasil penelitian, kategori tepat indikasi sebanyak 83 pasien $(100 \%)$.

\section{Tepat pasien}

Menurut Depkes RI (2006) pemberian obat dikatakan tepat pasien bila dalam pemberiannya dihubungkan dengan ketepatan dalam menilai kondisi pasien, dalam hal ini pemberian obat harus sesuai dengan kondisi pasien. Pemberian obat harus mempertimbangkan perbandingan efek terapi dan resiko. Berdasarkan hasil penelitian ketepatan pasien dalam penelitian ini diperoleh sebesar 83 pasien $(100 \%)$ tepat pasien.

\section{Tepat obat}

Ketepatan pemilihan obat merupakan keputusan untuk melakukan upaya terapi yang diambil setelah diagnosis ditegakkan dengan benar. Dengan demikian, obat yang dipilih harus yang memiliki efek terapi sesuai dengan spektrum penyakit. Hal ini berarti bahwa pemilihan obat harus berdasarkan jenis penyakit yang telah didiagnosa secara medis (Kemenkes RI, 2011). Berdasarkan hasil penelitian kategori ketepatan penggunaan obat dalam penelitian ini diperoleh sebesar 82 pasien $(98,8 \%)$. Hal ini disebabkan karena adanya ketidaktepatan pemberian kombinasi obat nikardipin dan nimodipin, sebagai antihipertensi pada nomor rekam medik 2 dengan diagnosa stroke hemoragik intraserebral. Sedangkan, menurut penelitian yang dilakukan oleh Wibowo dan Gofir (2001), kombinasi nikardipin dan nimodipin berfungsi sebagai profilaksis untuk mencegah vasopasme dan terbukti bermanfaar selama pengobatan akut perdarahan subarakhnoid. Penggunaan obat ini tidak dianjurkan untuk perdarahan intraserebral.

\section{Tepat Dosis}

Ketepatan dosis diartikan bahwa dosis, cara dan lama pemberian obat sangat berpengaruh terhadap efek terapi obat. Pemberian dosis yang berlebihan, khususnya untuk obat dengan rentang terapi yang sempit akan sangat beresiko timbulnya efek samping. Sebaliknya dosis yang terlalu kecil tidak akan menjamin tercapainya kadar terapi yang diharapkan (Kemenkes RI, 2011).

Berdasarkan hasil penelitian terhadap ketepatan dosis diperoleh sebanyak 73 pasien $(87,95 \%)$. Hal ini disebabkan, karena adanya ketidaktepatan dosis pada pemberian terapi antihipertensi. Pada nomor pasien 19, penggunaan obat amlodopin $60 \mathrm{mg}$ tiap 24 jam per hari. Berdasarkan JNC 7 dosis lazim amlodipin yaitu 2,5-10mg/hari tiap 24 jam. Pada nomor kasus 34, penggunaan obat furosemid $10 \mathrm{mg}$ tiap 8 jam per hari, hal dinyatakan tidak tepat dosis karena menurut JNC 7 dosis lazim dari penggunaan obat furosemid $20-80 \mathrm{mg} / \mathrm{hari}$ tiap 12 jam. Pada sebanyak 8 kasus terdapat ketidaktepatan dosis penggunaan obat nikardipin $10 \mathrm{mg}$ tiap 24 jam per hari, sedangkan menurut JNC 7 penggunaan dosis lazim dari obat nikardipin yaitu 30-90 $\mathrm{mg} /$ hari tiap 24 jam.

\section{KESIMPULAN}

Dari hasil penelitian diperoleh kesimpulan sebagai berikut, yaitu :

Pada penelitian ini diperoleh jumlah sampel sebanyak 83 pasien stroke hemoragik yang rawat inap di RSUP Prof. Dr. R. D. Kandou Manado pada periode Januari - Desember 2018, terdiri dari 70 pasien $(84,34 \%)$ mengalami stroke 
hemoragik intraserebral dan 13 pasien $(15,66 \%)$ mengalami stroke hemoragik subarakhnoid. Karakteristik pasien sebagian besar adalah laki-laki sebanyak 46 pasien $(55,42 \%)$ dan perempuan sebanyak 37 pasien $(44,58 \%)$. Rentang usia pasien stroke hemoragik terbesar pada usia 55-64 tahun sebanyak 27 pasien $(32,52 \%)$. Lama perawatan dengan prevalensi paling banyak, yaitu 1 - 5 hari pada 37 pasien $(44,57 \%)$. Hipertensi merupakan penyakit penyerta yang paling banyak diderita sebesar 60 pasien $(40,27 \%)$, dan kolestrol sebanyak 15 pasien $(10,06)$ Pola penggunaan obat pada pasien stroke hemoragik yang rawat inap di RSUP Prof. Dr. R. D. Kandou Manado dengan evaluasi tepat indikasi sebanyak 82 pasien $(98,8 \%)$, tepat pasien sebanyak 82 pasien $(98,8 \%)$, tepat obat sebanyak 83 pasien $(100 \%)$ dan tepat dosis sebanyak 73 pasien $(87,95 \%)$.

\section{SARAN}

Penelitian selanjutnya diharapkan dapat melakukan penelitian secara prospektif dengan melihat keadaan pasien selama dirawat di RSUP Prof. Dr. R. D. Kandou Manado.

\section{DAFTAR PUSTAKA}

Abraham NS, Hatky MA, Antman EM et al. 2010. A Foccused Updated of The ACCF/ACG/AHA 2008 Expert Consensus Document on Reducing The Gastrointestinal Risk of Antiplatelet Therapy and NSAID use: A Report of The American College of Cardiology Foundation Task Force on Expert Consensus Document, Circulation, 122:2619-2633
Adams H.P.,et al.,2003. Guidelines for The Early Management of Patients with Ischemic. Journal of The American Heart Association. 34:1056-83

Andrew ,M. Purnomo, Lidwina, S. Sangkey et al. 2016. Angka Kejadian Afasia Pada Stroke di Instalasi Rehabilitasi Medik RSUP Prof. Dr. R.D. Kandou Manado Tahun 2015. Jurnal e-Clinic $(2): 2$

Bereczki, D.,Liu, M., Prado, G. F., Fekete, I. 2000. Conchane Report : A Systemic Review of Mannitol Therapy for Acute Ischemic Stroke and Cerebral Parenchymal Hemorrhage. Stroke. 31: 2719-2722

Bladin CF, Alexandrov AV, Bellavance A, Bornstein N, Chambers B, Cote $\mathrm{R}$, et al. Seizures after stroke: a prospective multicenter study. Arch Neurol. 2000; 57(11):1617-22.

Deibert E, Diringer, M. N. 1999. The Intensive Care Management of Acute Stroke. The Neurologist. 5:313-25

Depkes RI. 2006. Pharmaceutical Care untuk Hipertensi. Departemen Kesehatan RI, Jakarta

Depkes RI. 2013. Badan Penelitian dan Pengembangan Kesehatan. Departemen Kesehatan RI, Jakarta

Ghani. 2016. Faktor Risiko Dominan Penderita Stroke Di Indonesia. Buletin Penelitian Kesehatan. Volume 44 (1) : 49-58 
Gunawan. 2009. Farmakologi dan Terapi

Edisi 5. Jakarta : Departemen Farmakologi dan Terapeutik akultas Kedokteran Universitas Indonesia

Johnsen SP, Svendsen ML, Ingeman A. 2012. Infection in Patients with Acute Stroke. The Open Infection Disease Journal, 6 (Suppl 1:M3) : 40-5

JNC 7. 2003. The Seventh Report of the Joint National Committe On Prevention, Detection, Evaluation, and Treatment of High Blood Pressure. Hypertension, 42:1206-52

Kemenkes RI. 2011. Laporan Nasional Riset Kesehatan Dasar. Jakarta

Kumar V, Abbas AK, Fausto N. 2005. Pathologic Basic of Disease. $7^{\text {th }}$ ed. Philadelphia: Elsavier Saunders, 270-5

Louis RC, Joseph PB, Ralph LS. 2015.

American Heart Association An Updated Definition of Stroke for the 21st Century: A Statement for Healthcare

Meita Krismayanti. 2007. Evaluasi DRP Pada Pengobatan Pasien Stroke Di Instalasi Rawat Inap Rumah Sakit Panti Rapih Yogyakarta. Fakultas Farmasi Universitas Sanata Dharma

Misbach. 2001. Pandangan Umum Mengenai Stroke. Jakarta : Balai Penerbit FK Universitas Indonesia

Munaf. 2004. Pengantar Farmakologi. Kumpulan Kuliah Farmakologi Edisi 2. Jakarta : Penerbit Buku Kedokteran EGC
Jagtap P. N. 2013. Stroke: A Brain Attack. IOSR J Pharm 3:1-23

PERDOSSI. 2011. Guideline Stroke Tahun 2011. Jakarta : PERDOSSI

Rincon and Mayer. 2005. Clinial Review: Critical Care Management of Spontaneous Intracerebral Hemorrhage 12:237

Silva, D. A. D, Narayanaswamy et al. 2014. Understanding Stroke A Guide for Stroke Survivors and Their Families.

Wibowo dan Gofir. 2001. Farmakoterapi Dalam Neurologi. Jakarta : Salemba Medika

WHO. 2016. Stroke. A Global Response is Needed 